\title{
Drainage network development in the Pannonian Basin
}

\author{
FERENC SCHWEITZER ${ }^{1}$
}

\begin{abstract}
The evolution and development of the greatest rivers in the Pannonian Basin have been investigated for almost 150 years. At the end of the Late Miocene Sub-Epoch (7.5-5.3 Ma BP) and at the beginning of Pliocene Epoch (5.3-4.5 Ma BP) Lake Pannon shrank dramatically, filled up with sediments and completely dried up as a result of global climate change (Bérbaltavárian /Messinian/ Stage). In the basin dominated by dry climate conditions, torrents bordered with riparian forests appeared. During the Lower Pannonian Stage (Eppelsheimium in the Hungarian terminology) the tropic rainforests which previously had covered even regions at higher latitudes contracted to a smaller area around the Equator due to the global climate change. Then under the warm and humid climate of the Middle and Late Pliocene (Csarnotanian and Ruscinian Stages, 4-3 Ma BP) tropic rainforests expanded again and the drainage network development of the Pannonian Basin continuing even today started. During our research, climate-indicating travertine layers covering the terraces, travertine stratigraphy and fauna findings were investigated.
\end{abstract}

Keywords: travertine stratigraphy, plate movements, global climate change, fluvial and abrasive terraces, pediments, evolution of River Danube

\section{River and history}

According to the archives, the word Danube was already known as early as in the $7^{\text {th }}$ century BC. The Greek called its lower river section situated between the Iron Gates and the Black Sea Ister. After occupying Illyria in 168 BC, the Romans called the river Danubius and they established that Ister and Danubius were the same river. Julius Caesar used the name Danube for the first time. The river was worshipped as a deity during the Roman Empire (KÁDÁr, L. 1980). The word Danube is of Celtic origin and it means "water", "river". It was transmitted into the Hungarian language by the northern Slavic nations. Its foreign versions (Danube, Donau, Danubio, Dunaj, Dunarea, Dunav, etc.) are of ancient origin as well.
The headspring of the river Danube has not been known for so long as it would be expected. Herodotus (484-408 BC) believed that the source of the Danube was in the Pyrenees. During the Second Punic War (218-201 BC) the Romans realized while they were crossing the lower section of Rhone that Herodotus had been wrong. Later, they suspected that the Danube originated in the mountains of Bretagne away from the Pyrenees. However, that presumption was proved to be mistaken, too. The false assumption was clarified during the Gallic Wars (58-51 BC) waged by the Roman proconsul Julius Caesar who, however, did not manage to find the spring of the Danube and assumed that the river originated in the Southern Alps. In the end, the source of the river, namely the Black Forest was discovered only in 14-16 AD.

\footnotetext{
${ }^{1}$ Professor emeritus, Geographical Institute RCAES HAS, H-1112 Budapest, Budaörsi út. 45.

E-mail: schweitzer.ferenc@csfk.mta.hu
} 
The Danube has been involved in several significant events of world history, just to mention some of them: Attila the Hun, the leader of the Hunnic Empire rushed along the Danube (406-453 AD) as far as the Catalaunian Plains to fight with the Western world. Charlemagne and his troops also marched along the river to put down the reign of the Avars. The Danube is the second longest river in Europe (after the Volga). The total length of the river is $2,860 \mathrm{~km}$, including the Hungarian section as long as $417 \mathrm{~km}$. The $140-\mathrm{km}$-long river section between Oroszvár and the Ipoly estuary (Szob) marks the border between Hungary and Slovakia. The Danube reaches Hungary as a large river.

\section{The Hungarian section of the Danube}

As a result of river regulations, the Hungarian section of the Danube is not entirely navigable. The river regulations carried out at the end of the $19^{\text {th }}$ century and at the beginning of the $20^{\text {th }}$ century converted the natural river into an artificial channel.

The Danube enters the Little Hungarian Plain at the meeting point of the Alps and the White Carpathians at $130 \mathrm{~m}$ a.s.l. After flowing through the so called "Porta Hungarica" at Devin (today a district of Bratislava), the Danube reaches the Little Hungarian Plain transporting an immense amount of alluvial sediments (pebbles, sand, silt). The sediment transport mainly results from floods, the frequency of which has decreased significantly since the construction of the Austrian and Slovakian dams (Gabčíkovo Dams).

The largest European island can be found in the Little Hungarian Plain. It is called "Golden Garden", involving the Szigetköz as the Hungarian part and the Zitny Ostrov (in Hungarian 'Csallóköz'), as the Slovakian part of the alluvial fan. The vicinity of the two regions is an endless plain, the surface of which is built up of point bars. The Danube flows on the top of the alluvial fan where the main channel had changed its direction quite frequently before the river regulation works. River bar evolution made the Danube meander and change its flow resulting in the development of several alluvial fans. Thus, the Danube had no main channel even at the beginning of the $19^{\text {th }}$ century.

The archeological findings confirm that the navigable main channel of the Roman era is equivalent to the contemporary Moson Danube. The region also serves as one of the most significant drinking water supply of the northern part of the Transdanubia and the southern part of Slovakia. The gold of the "Golden Garden" is the drinking water itself. The main responsibility of the authorities and the scientific world is to preserve that treasure. It is a fundamental interest to restore the water balance prior to the construction of the Gabčíkovo Dams to maintain and protect the strategic drinking water supplies. The water regime and the water balance of the Danube are controlled mainly by the precipitation received by the catchment areas of the Austrian Alps and Prealps as well as the melt water of snow and glaciers.

\section{Fluvial land-forming processes of the Danube}

The immediate vicinity of the river is formed by river-bed changes. The Hungarian section of the river can be characterized by river down-cutting and valley filling. Upper courses are rare along the Hungarian section of the river. Even the Visegrád Gorge cannot be considered as a pure incising valley type as point bars can be observed in several places. Valley filling is not very frequent either, rather a transient type of cutting and filling. There are river sections where river downcutting is as frequent as valley filling. In that case erosion and deposition alternate each other. That's why the valley is neither down cut nor filled with alluvium to a great extent. For example, between Bratislava (Slovakia) and Gönyü (Hungary) filling is the most typical river function, therefore, most of the Danube sediment reaching the country are deposited there. The (relatively fast) fluvial deposition resulted in the development of 
anabranches. Between Gönyű and Komárom not only deposition but also transportation can be detected since the bedload is partly transported away.

The huge alluvial fan consists of two types: a younger, low-lying alluvial plain, involving Szigetköz, the Moson Plain and the Hanság Plain with the alluvial plain of River Rába. The older and higher situated deltaic and alluvial plain involves, among others, the Parndorf Plain and the Bana Hill (Figure 1).

At the northern edge of the Gerecse Hills, the flood plain of the Danube becomes narrower, at Esztergom it widens again, then in the Visegrád Gorge it is only narrow strips following the river banks. Between Vác and Budapest the floodplain of the river is welldefined with clear boundaries, characterized by embayments of various size. It follows the river, especially the left riverbank as far as the southern boundary of the country with a varying width (15-25 km). In many places, both on the right and left riverbanks, extensive depressions occupy the floodplain (Bulla, B. 1941; Erdélyi, M. 1955; Pécsi, M. 1959; Scheuer, Gy. and Schweitzer, F. 1984). Some examples: the Kalocsa and the Baja Depressions on the left riverbank; the Érd, the Adony, the Paks-Tengelic-Sárköz and the
Mohács Depressions on the right riverbank dissected by landslide-effected high bluffs of 40-50 m height. Lots of islands are attached to the feet of the bluffs which are the remnants of larger landslides eroded by the Danube.

The current Danube is flowing from North to South. According to the geomorphologic investigations and radiometric data, during the last interglacial period which was warm and humid, the direction of flow of the Danube was NW-SE, therefore the river was flowing through the Danube-Tisza Interfluve. The direction of flow followed the series of depressions getting younger and younger southwards. However, the Danube changed its direction over time and started to erode the high bluffs of the right Danube riverbank descending in the direction of the Danube-Tisza Interfluve. The area of high bluffs was as wide as $10-15 \mathrm{~km}$ and it stretched as far as the western edge of the current Danube-Tisza Interfluve 80,000100,000 years ago. The Solt Hill and the Tétel Hill are buttes representing the remnants of the former bluff of Mezőföld (Figure 2).

The sand dunes of Illancs being an alluvial fan (172 $\mathrm{m}$ a.s.l) also originate from Mezőföld. The alluvial fan had evolved before the Danube changed its direction of flow.

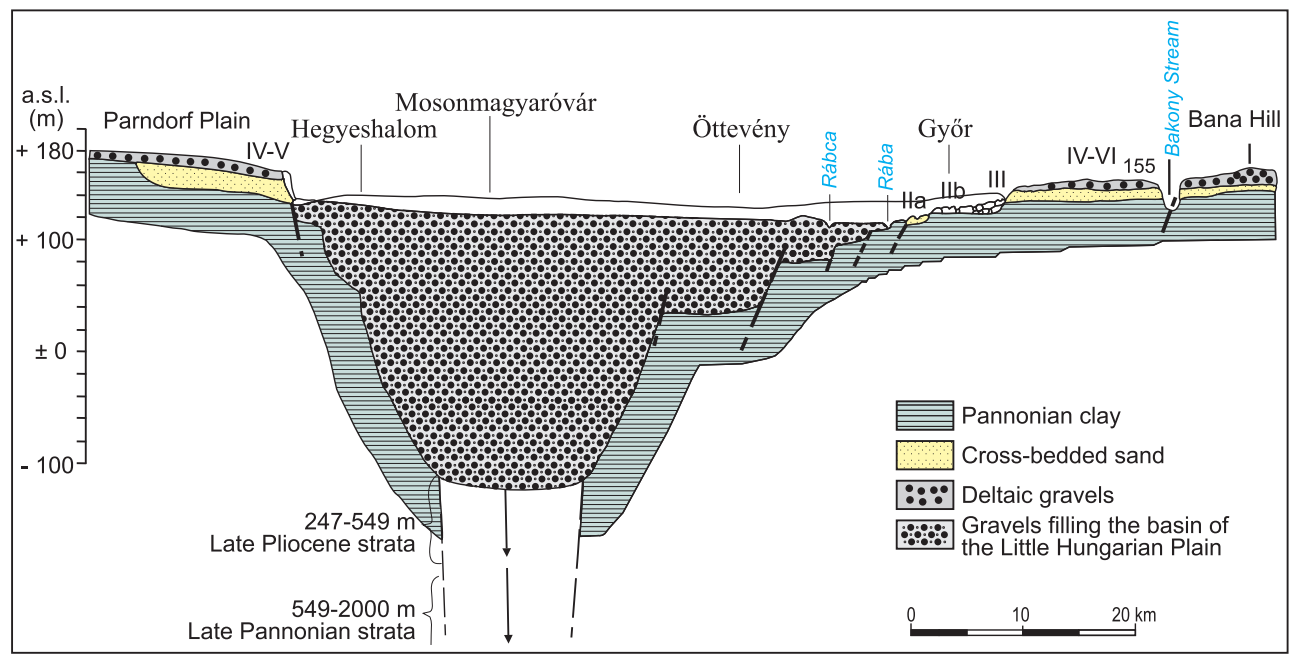

Fig. 1. The area between the Parndorf Plain and the Bana Hill (by Pécsi, M. 1959) 


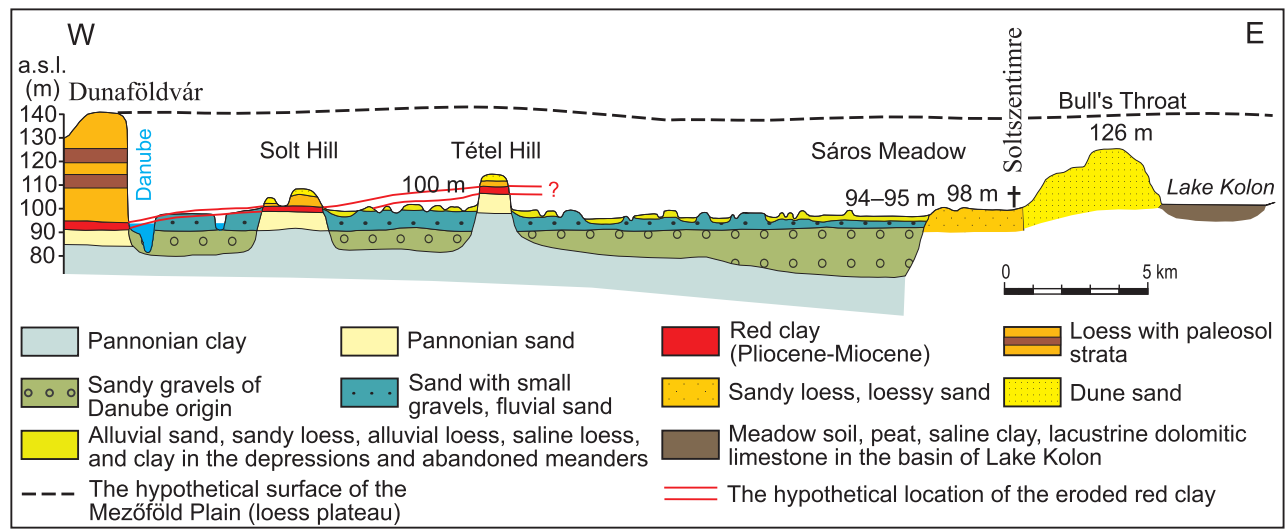

Fig. 2. The terrain and geologic cross-section of the Solt Plain. Based on the data by ErdéLYI, M. and SüMEGHY, J. (Ed. by PÉcsi, M. 1959)

\section{The evolution of the Danube in brief}

The evolution of the "ancient" Danube as well as that of the current river have taken a long a time, the duration of which cannot be measured in decades and centuries but in geologic time. So it is not a coincidence that the history of Central Europe's largest river has been investigated for almost 150 years (SóbÁNYI, GY. 1893; Halaváts, GY. 1898; CvijIć, J. 1908, 1910; Lóczy, L. 1913; STRÖMPL, G. 1913; Сноцnoky, J. 1929; Noszky, J. 1933; Prinz, Gy. 1936; SzÁdeczKy-Kardoss, E. 1939; Bulla, B. 1941; Mottr, M. 1941; Mihálcz, I. 1953; SÜMEghY, J. 1953; FinK, J. and MaJdAN, H. 1954; KÁDÁR, L. 1955; KÉZ, A. 1956; PÉcsI, M. 1959; Scheuer, Gy. and Schweitzer, F. 1988; GÁBris, Gy. 2006).

During that period several theories have come into being. The aim has been to locate the gravel deposits situated above 300-330 m a.s.l. and below $100-110 \mathrm{~m}$ a.s.l. in time according to the relevant scientific disciplines. Most of the syntheses (PencK, A. 1894) are in connection with theories on climatically induced fluvial terraces classified by Alpine glacial chronology. Geomorphologists associate the evolution of the fluvial terraces of the Danube with the fluvial system changes related to the last four major Alpine glaciations.
The floodplain is supposed to be of Holocene age, the above lying four gravel-covered terraces are probably of Alpine glacial origin, namely the four Alpine glaciations (KÉz ,A. 1934; Bulla, B. 1941, 1956). It was first investigated by Сноцnоку, J. (1915), later by Kéz, A. (1934), KRiván, P. (1953) and Pécsi, M. (1959).

The difficulties of the issue are well-represented in the fact that due to lack of gravels, Márton PÉcsi could not correlate the terraces located at greater height in the Visegrád Gorge (190-210 m a.s.l. and 240-270 m a.s.1.) (PÉcsI, M. 1959). Several scientists dispute even the Danube origin of the pebbles located mostly at a higher level (VADÁsz, E. - ex verbis, PÉCSI, M. 1959; LÁNG, S. 1955).

First, it was not easy for scientists to identify the period currently known as Pliocene Epoch between the end of the Pannonian Stage and the beginning of the Pleistocene Epoch extending from 5.3 million to 2.5 million years ago. The existence of the river presently known as the "Danube" during the Pliocene Epoch was not an evidence. On the basis of hypotheses by KÉz, A. (1934), SzádeczKy-Kardoss, E. (1939), Bulla, B. (1941), KÜPper, H. (1953), KÁDÁR, L. (1955), PÉcsi, M. (1959), FinK, J. (1961) and Thenius, E. (1978) associated the development of the 
river in the Vienna Basin with the beginning of the Pleistocene Epoch including Early, Middle and Late Pleistocene sub-epochs and extending from Günz till Würm according to the Alpine glacial chronology. The lower boundary of the Pleistocene Epoch was identified as the boundary between the Matuyama and Brunhes Chronozones. Only a few scientists suspected that some of the highest-lying terraces covered with gravels could be older and might have developed during the Late Pliocene Epoch, however, their development was not explained by climate change but plate tectonics (Bulla, B. 1941, 1956; PÉCSI, M. 1959).

In the 1930's and 1940's defining the boundary between the Pliocene and the Pleistocene Epochs was a controversial issue. Some scientists suggested that the so called Upper Levantine strata should be reclassified as Lower Pleistocene strata therefore the incision of the Danube at Visegrád could be classified as an Upper Pliocene event. According to the current nomenclature, the Pliocene Epoch started 5.3 million years ago when the Strait of Gibraltar opened. At that time the vast ice sheet which had developed around the South Pole during a glacial period prior to the quaternary glaciation started to melt which resulted in global sea level rise and the opening of the Strait of Gibraltar (Haq, B.U. et al. 1987; Schweitzer, F. 2004) (Figure 3). That geological event took place under a warm and humid subtropical climate during the Csarnotanian and Ruscinian Stages (4.3-4 Ma BP) (Figure 4).

Owing to the significant amount of precipitation, the fluvial erosion became dominant in the Carpathian Basin. Besides weathering, red clay deposition, valley formation, the dissection of pediments and landslides were typical. The karst systems were filled up with water, the karst groundwater levels rose which resulted in the resurgence of karst springs depositing travertine at the base level. According to PÉcSI, M. (1980), the oldest Danube terraces located at 230-240 m a.s.l, 280-300 m a.s.l. and 300-330 m a.s.l. were formed during the mentioned period (terraces No. VIII, VII, VI).
The Ruscinian-Csarnotanian Stages were followed by the so called Late Villafranchian (Villanyian) Stage (3.0-1.8 Ma BP), the fauna and climatic conditions of which suggest similar ecological conditions to those of the Bérbaltavárian Stage (Kretzoi, M. 1983; Kordos, L. 1991, 1992). The disappearance of the subtropical fauna of the warm and humid Csarnotanian Stage and the quick intrusion of the heat and dry tolerant steppe fauna refers to the dominance of continental climate with little precipitation.

During Villanyian Stage lasting for 1.2 million years, fluvial erosion was not significant because of lack of water. Fluvial terraces did not evolve, only debris cones, "meridionalis pebbles" (Kisláng), wide and shallow wadis developed owing to the low amount of seasonal precipitation.

In the Gerecse Hills fluvial gravels cannot be detected in the substrata of travertine (the lower pediment) situated, according to PécsI, on the terraces No. VI-VII. at 200-220 m a.s.l. and 230-240 $\mathrm{m}$ a.s.l. due to the warm and dry climate (Figure 5, Photo 1). The sporadic pebbles involve pebbles which eroded from upper levels and redeposited on the lower-lying Villanyian pediment, and flesh-colored, varnish coated, sporadic pebbles which redeposited in the tetarata basin containing the Kisláng fauna.

The paleomagnetic analyses confirmed that the travertine covering the Danube terrace No. V. at $180 \mathrm{~m}$ a.s.l. and the underlying terrace material had been developed at the beginning of Matuyama paleomagnetic era and during the Jaramillo geomagnetic events. The relative chronological age of the fossil fauna found in travertine deposits also reinforced the results above (Jánossy, D. 1979; SCHEuer, Gr. and Schweitzer, F. 1988) (Figure 6).

The Mediterranean Sea started to cool about 2.0-2.2 million years ago (Funder, S. et al. 1985).

The most obvious first sign of global climate cooling was the appearance of North Sea fauna species in the Mediterranean Sea. The cooling was enhanced by the ice sheet becoming permanent and ever growing around the 


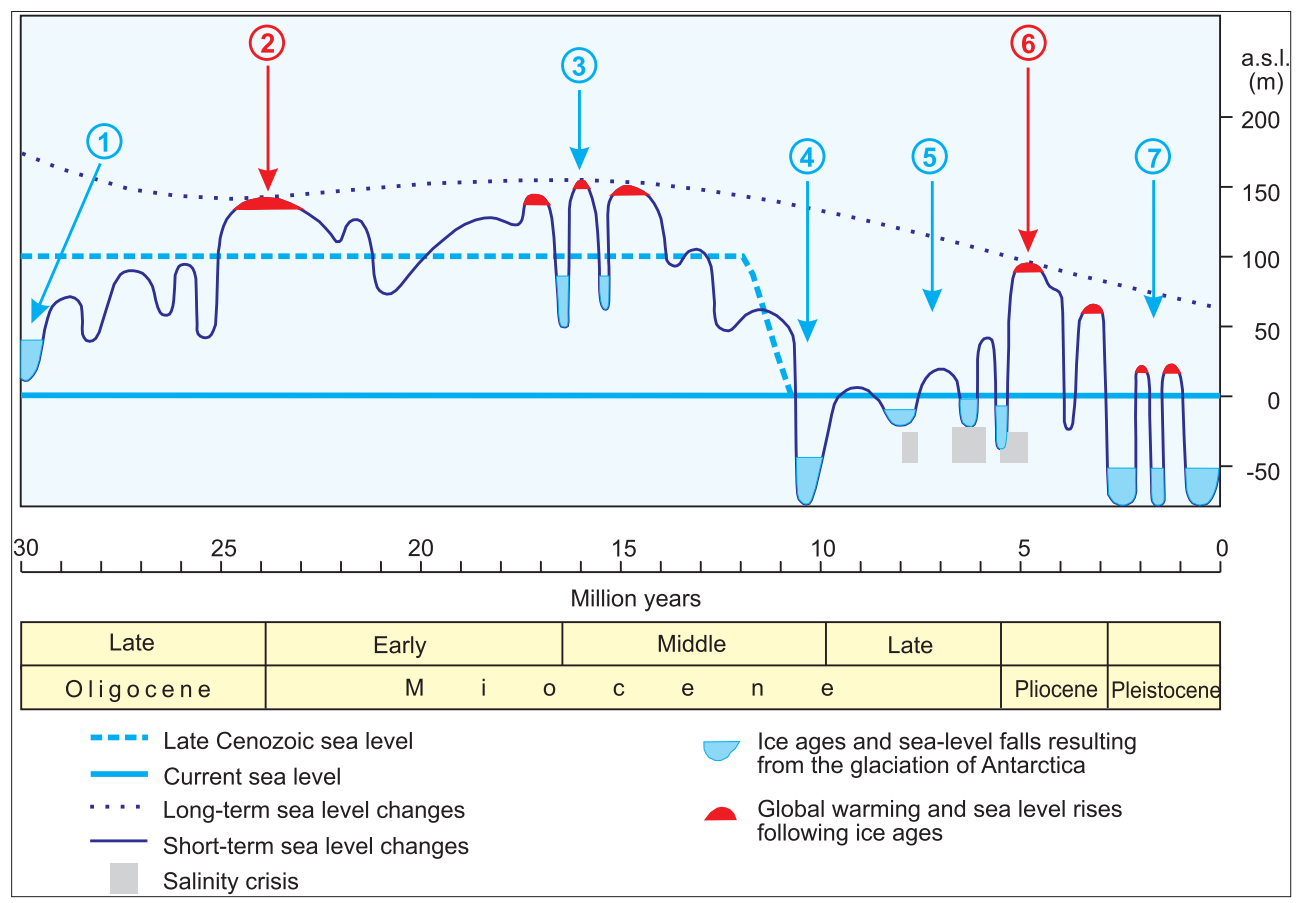

Fig. 3. The possibility of ice ages in the Late Cenozoic (eustatic sea-level changes by SchweItzer, F. 2004, based on $\mathrm{HAQ}_{\mathrm{A}}$, B.U. et al. 1987). -1 = The Antarctica floated to the South Pole and it started to glaciate (32-30 million Ma BP); 2 = According to $\mathrm{HAQ}_{\mathrm{AQ}}$ B.U. et al. (1987) the average global temperature rose by $3-6{ }^{\circ} \mathrm{C} ; 3=\mathrm{During}$ the Badenian Stage (17.2 Ma BP, by STEINIGER, F.F. 1999) a significant marine regression and the further glaciation of the Antarctica were likely to take place. Thanks to the continental link between Eurasia and America, Anchitherium species (pre-historic horse) migrated into Eurasia from Alaska and after the withdrawal of the Paratethys, Miomastodon-Zigolophodon species (mastodon) moved from Africa to Europe; $4=$ Further probable glaciation of the Antarctica during the Sarmatian Stage; Hipparion invasion from North America across the Bering Strait due to marine regression ("Hipparion Datum"); 5 = Miocene/Pliocene boundary; shifting from brackish-water sedimentation (Congeria) to freshwater sedimentation (Unio); Lake Pannon was accumulated and it dried up; the re-glaciation of the Antarctica (7-6 Ma BP) referring to global climate change, e.g. the desertification of North China (6.2-5 million Ma BP); 6 = During the Csarnotanian-Ruscinian Stages (4.4-3 $\mathrm{Ma} \mathrm{BP})$ the Antarctic and the Greenland ice sheets completely melted; the coastal water temperature rose by 8-10 ${ }^{\circ} \mathrm{C}$; the global sea level was $80-100 \mathrm{~m}$ higher than today; $7=$ Pleistocene glaciations; the global sea level decreased again; a continental link was re-exposed between North America and Eurasia (2.5-0.01 Ma BP); the development of terrestrial ice sheets ("Equus Datum")

North Pole. The climax of the process started 1.0-1.2 million years ago (ZubaKov, V.A. and BorzenKova, I.I. 1990) also representing the boundary between the Upper and Lower Biharian stages introduced by KRETzor and the starting point of a significant climate cooling in the Carpathian Basin resulting in the development of further Danube terraces (terrace No. IV. /350,000 Th-U years/, No. III.
/190,000 Th-U years/, No. II/b /120-90,000 Th-U years/, No. II/a /30-12,000 C ${ }^{14}$ years/, No. I. /11,000 C ${ }^{14}$ years /). In 2006 GÁBRIS, Gy. among others, make an attempt to give a new explanation for the evolution and the chronological order of the Hungarian fluvial terraces, including, of course, the Danube terraces for the period starting with the Jaramillo subchron. 


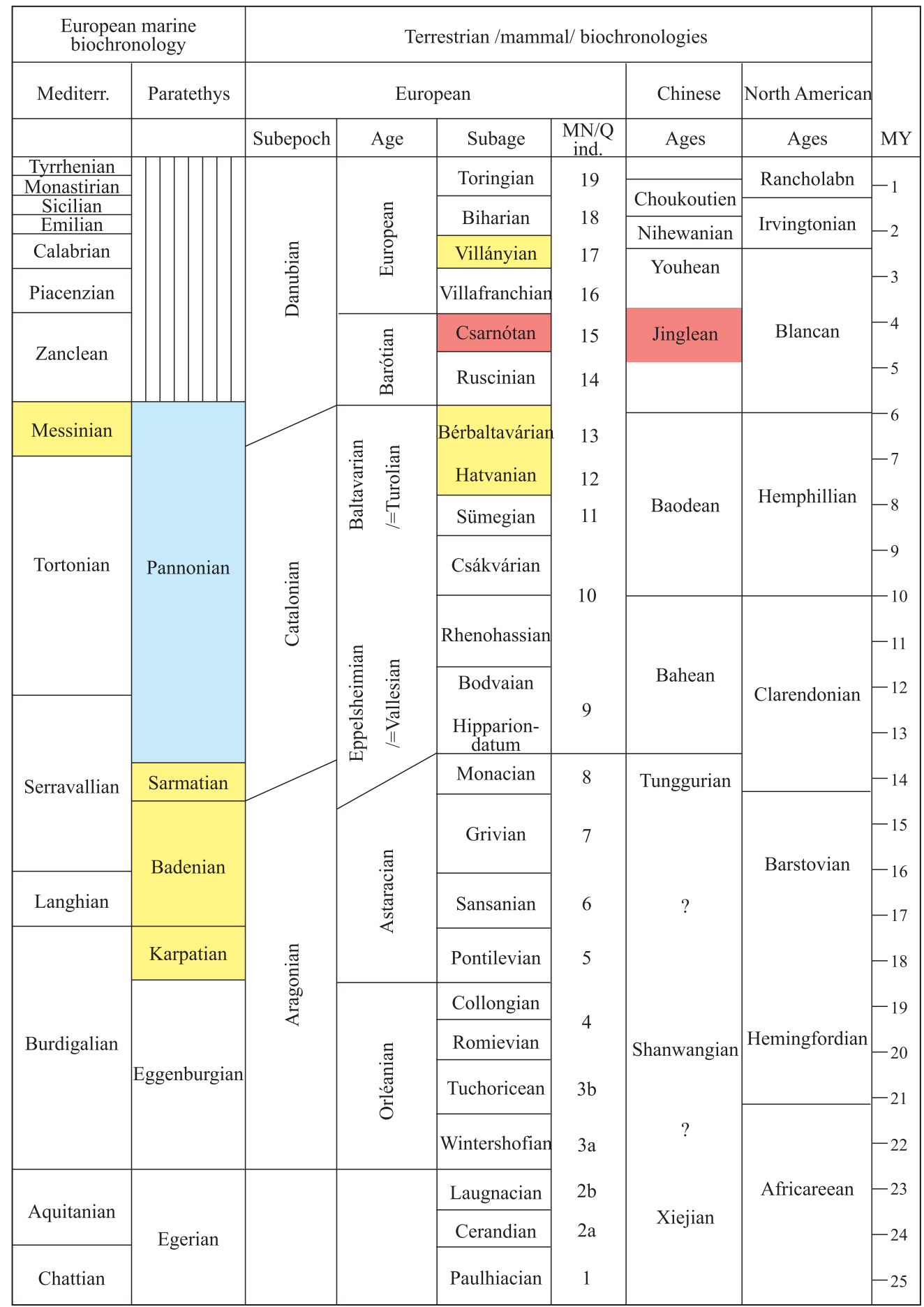

Fig. 4. Late Cenozoic biostratigraphic correlation between Asia and Europe (based on the works of KrETzoI, M.) 


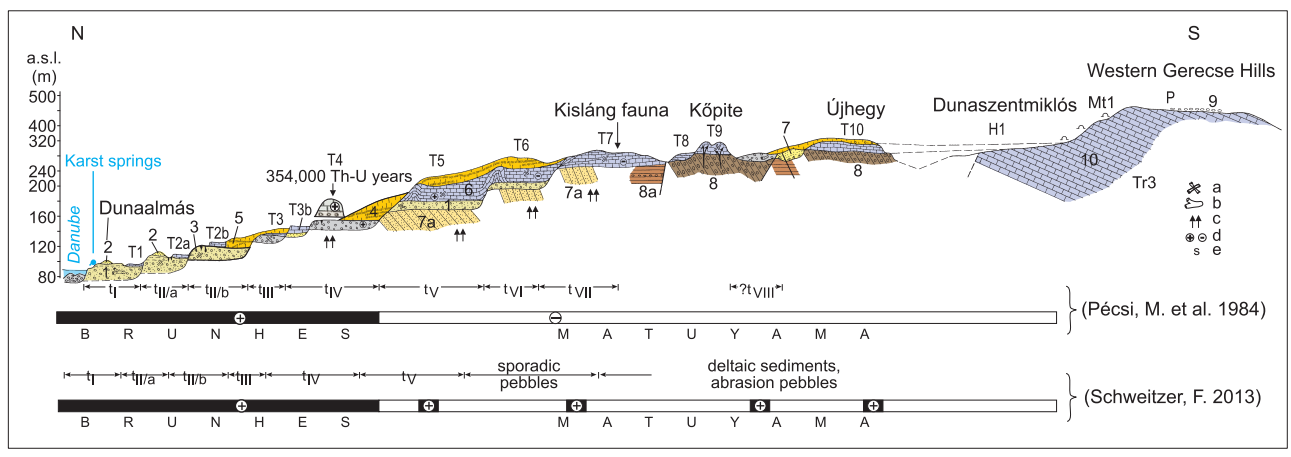

Fig. 5. Geomorphologic levels of Western Gerecse Hills along the section between Dunaalmás and Dunaszentmiklós. Based on figure by Pécsi, M. et al. 1985 (re-edited by SchweItzer, F. 2013) - 1= Fluvial terrace gravels and sand. The gravels of the presumed terrace No. VIII (numbered by PÉcsi, M.) deposited on the Upper Pannonian deltaic gravels by eroding the Upper Pannonian sandy deposits consisting of sand and pea gravels represent erosive discordance; 2 = Quicksand; 3 = Remnants of Pleistocene cryoturbation; $4=$ Loess, slope loess; 5 = Fossil soils in loess; 6 = Travertine levels (T1-T10); 7 = Upper Pannonian cross-bedded sand (?), Bérbaltavarian Stage; 8 = Upper Pannonian clay; 9 = Miocene terrestrial gravels; 10 = Late Triassic limestone; $\mathrm{H} 1$ = Remnants of Late Pliocene pediment; at the edge of the pediment. The Upper Pannonian abrasion terrace No. 2 is superimposed; Mt1 = Upper Pannonian abrasion terrace; P = Pre-Tertiary and Tertiary planation surface with Miocene terrestrial gravel patches (?); $a=$ fauna site; $b=$ carbonized tree trunk remnant; $c=$ funnel-shaped traces in travertine and gravels created by thermal spas; $\mathrm{d}=$ paleomagnetic polarity; $\mathrm{e}=\mathrm{sporadic}$ gravels on the lower-lying pediments

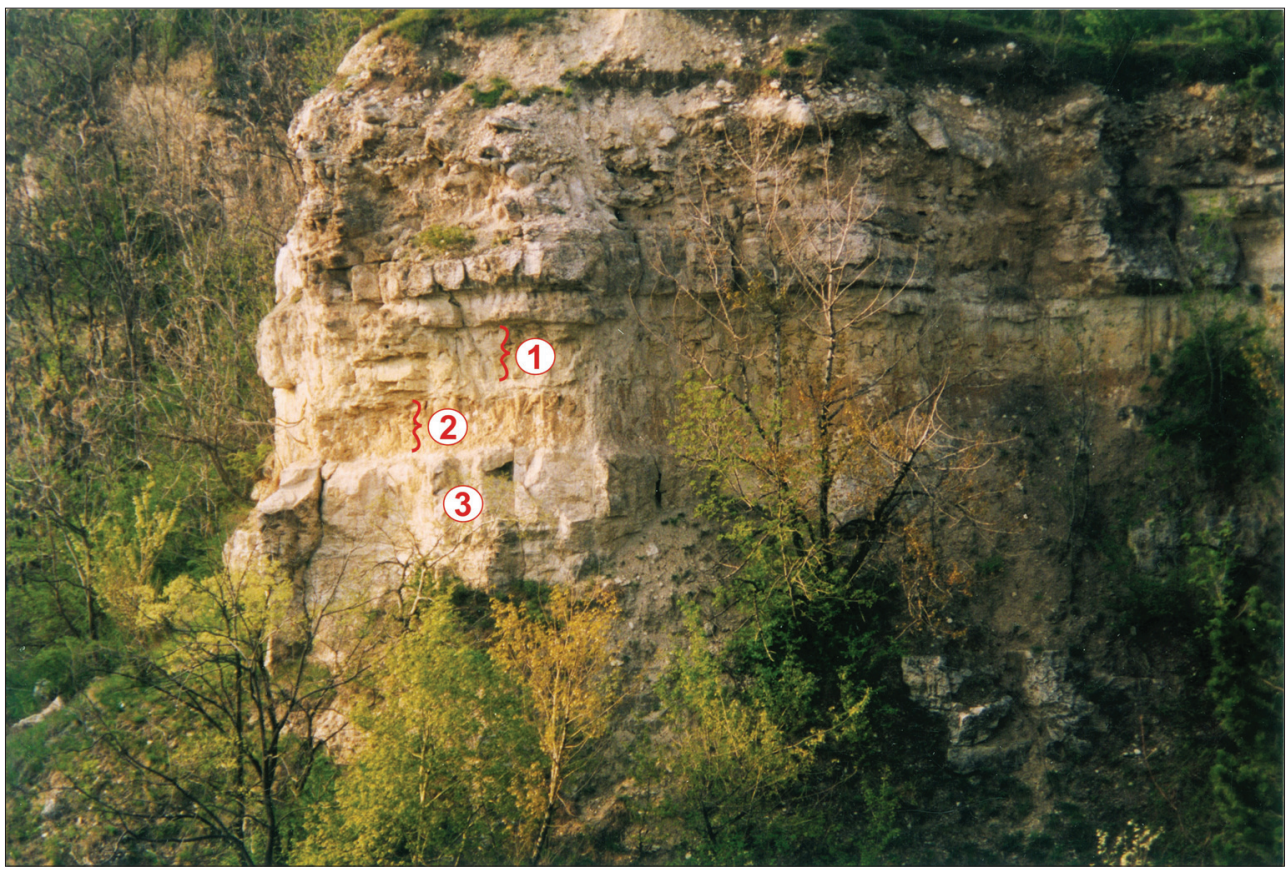

Photo 1. The Kisláng fauna having developed during the Olduvai event was embedded in travertine at Dunaalmás) - 1 = Old loess deposited during Olduvai geomagnetic polarity event; 2 = Kisláng fauna site; 3 = Travertine layers (Photo by SchweITzeR, F.) 


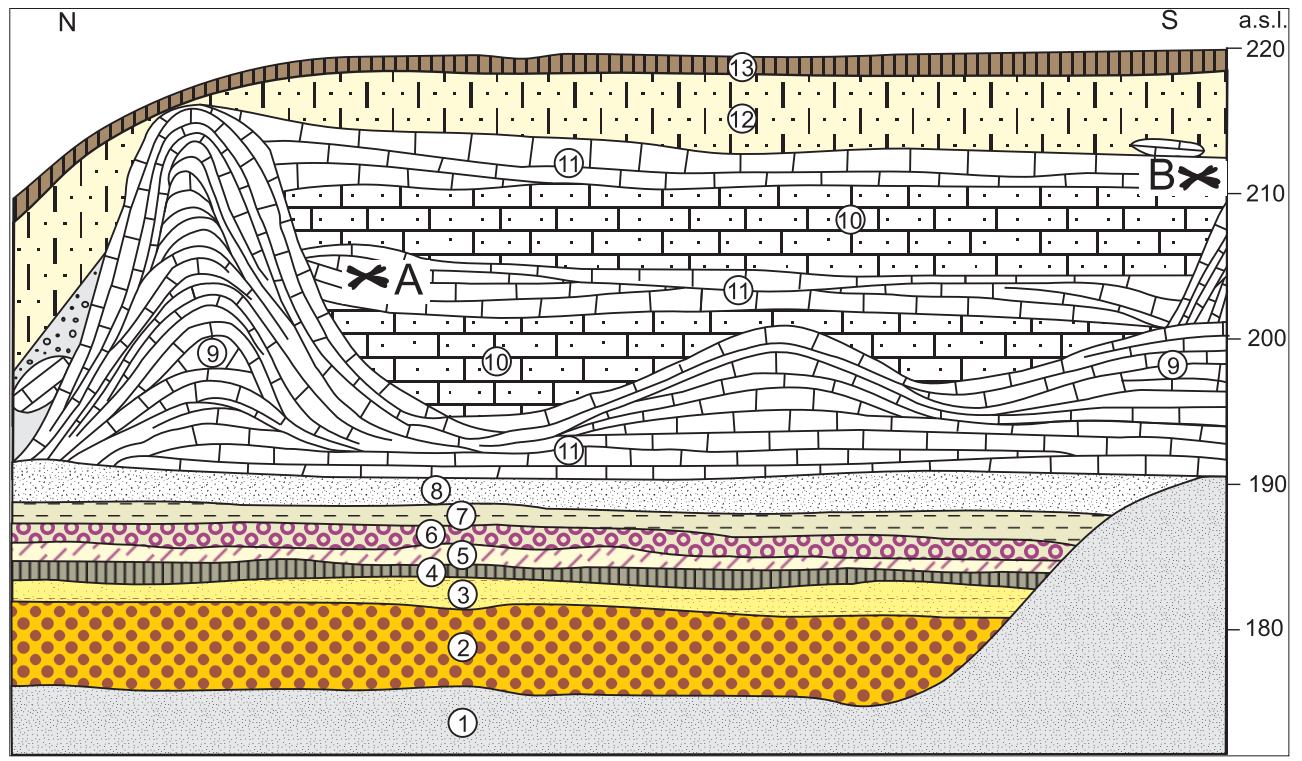

Fig. 6. Travertine level No. V, the exposure of a tetarata basin. The travertine deposited on the Danube terrace No. V. (by Schweitzer, F.) - 1 = Upper Pannonian yellow medium sand; 2 = sandy gravels deposited on Danube terrace No. V.; 3 = sand with gravel; 4 = sand; 5 = light yellow clay with embedded travertine and quartz pebbles and travertine layers of $1-5 \mathrm{~cm}$ width; 6 = yellowish grey silt with embedded travertine and quartz pebbles; 7 = yellowish grey calcareous, sandy silt; 8 = calcareous sand; $9=$ tetarata dams; 10 = fluvial sand, calcareous silt; 11 = travertine bed; 12 = sandy loess; 13 = recent soil; A = Clemmys méhelyi Kormos (=Emys orbicularis L.),

Megaloceros sp.; B = Archidiskodon meridionaris (planifrons) finding, reversed polarity (Jaramillo?)

\section{The ancient Visegrád Gorge}

The ancient Danube in the Late Miocene

The Pannonian Sea (later only a lake) having been the last sea in the Carpathian Basin was withdrawing rapidly and it was completely accumulated (Figure 7). As a result of the Pannonian transgression, thick layers of pebbles (Hollabrunn-Mistelbach Formation) originating from the deltaic sediments of rivers flowing into the Pannonian Sea were deposited NEE of Krems (Schlesinger, G. 1912; FinK, J. 1961, 1967; Thenius, E. 1978). The gravel deposits can be found from the Vienna Basin along the northern edge of the Dunazug Hills as far as the Pest Plain (Mogyoród).

The geomorphological situation of gravel deposits in the Vienna Basin is similar to that of abrasion pebbles, deltaic gravels and travertine (Új Hill, Süttő Hill / Tapirus Arvernensis, Anancus Arvernensis, Archidiscodon Meridionalis/, Köpite Hill /Anancus Arvernensis/, Muzsla Hill /Derissena Auricularis/, Poc-kő Hill) situated at 300-330 m a.s.l. in Gerecse Hills and deltaic gravels in Mogyoród cemented with travertine containing the fossils of Hipparion, Melanopsis aquensis GRAT, Viviparius sadleri PARTSCH, Bithinia proxima FUSCH and covered with bentonite deposits of 1-2 $\mathrm{m}$ width in some places (Scheuer, Gy. and Schweitzer, F. 1984; Schweitzer, F. 1993) (Photos 2-6).

Presumably, the deltaic gravels were not deposited by the ancient Danube but during the accumulation of Paratethys. There were probably flat or low-situated piedmont plains formed and dissected by the anabranching consequent streams of the 


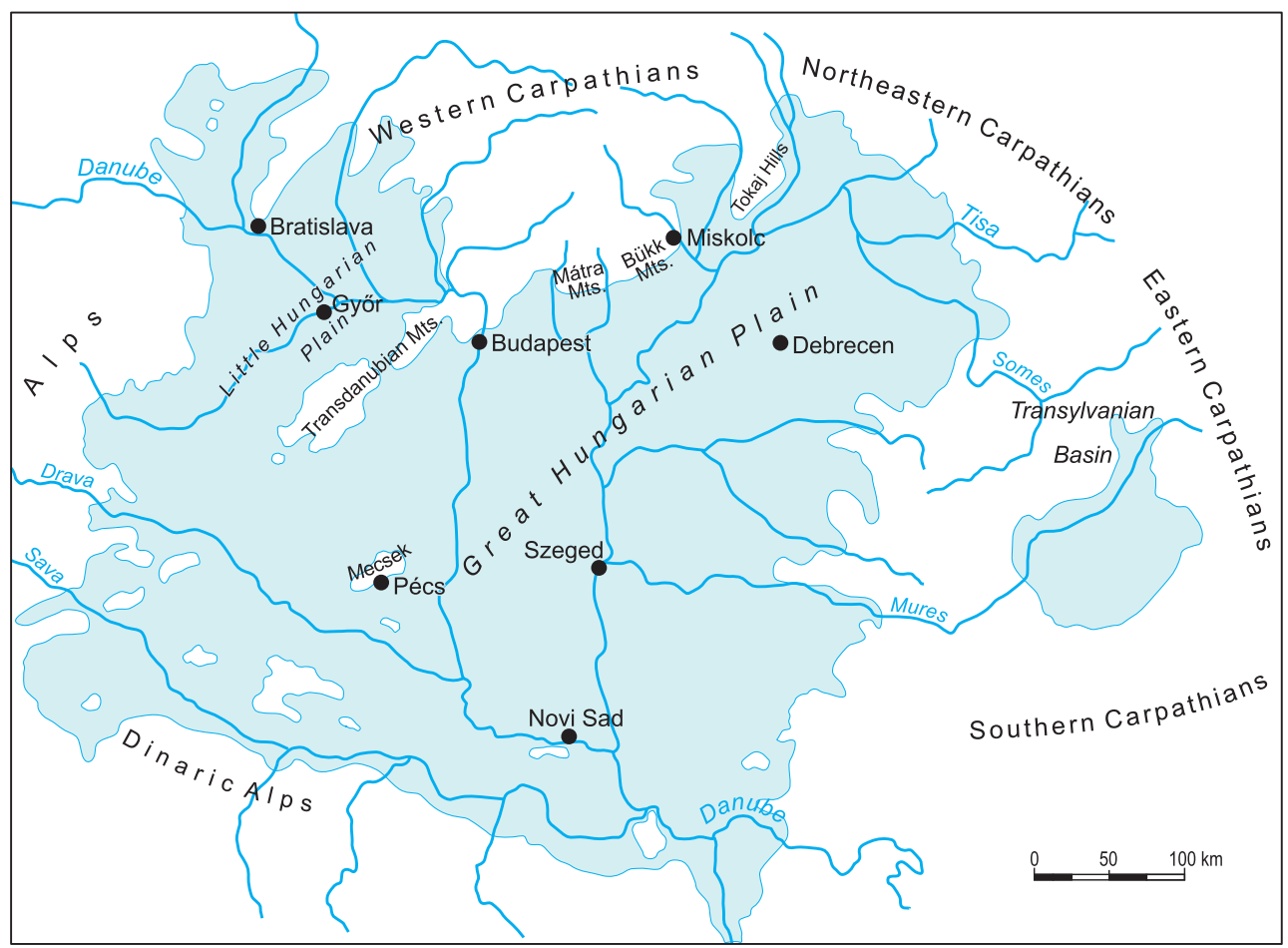

Fig. 7. The greatest extension of Lake Pannon in the Carpathian Basin (by Jámвor, Á. et al. 1987)

Alps and the Northern Carpathians which deposited deltaic gravels of several meters width (Photo 7).

Besides the Vienna Basin (PAPp, A. 1950), gravel deposits can be found at the NNE margin of the Pest Plain, at the northern rim of the Gerecse Hills at Dunaalmás, Süttő, Lábatlan, etc. The deltaic gravel layers deposited at the former base level of erosion are covered or dissected by Upper Pannonian travertine deposits at Öreg Hill in Dunaalmás (330 m a.s.1.), in Dunaszentmiklós (325 m a.s.1.), in Alsóvadács (335 $\mathrm{m}$ a.s.1.) or in the Vienna Basin at $360 \mathrm{~m}$ a.s.l. and below, for example at Trautmannsdorf where deltaic gravels deposited over Congeria neum layers.

Simultaneously, with the basaltic volcanism as old as 7-8 million years, the ridge of the Transdanubian Mountains - Gleichenberg Ridge was raised. As a result of that, Rába changed its direction to the NE, the Danube and its tributaries changed their directions to the E, flowing along the northern edge of the Gerecse Hills, all together towards the "Visegrád Gorge" which presumably existed 12-13 million years ago. Later, the Danube broke through the strait towards the Hungarian Great Plain and flooded the lowlands (SAlamon, F. 1878; PÉCSI, M. 1985). There are two evidences for the existence of the strait: the remnants of geysers evolved on the geomorphological surface situated at the height of $260-270 \mathrm{~m}$ a.s.l., in the vicinity of Szokolya and Magyarkút, and the quartz pebbles located on the right rim of the Szokolya Basin at the height of 310-350 m a.s.1., E-SE of Királyrét. Increasing the distance from Szokolya-Királyrét in the direction of Vác, South of Kismaros, the pebble deposits are getting thinner (Figure 8).

A great interfluve ridge seems to have evolved between Visegrád and Verőce cre- 

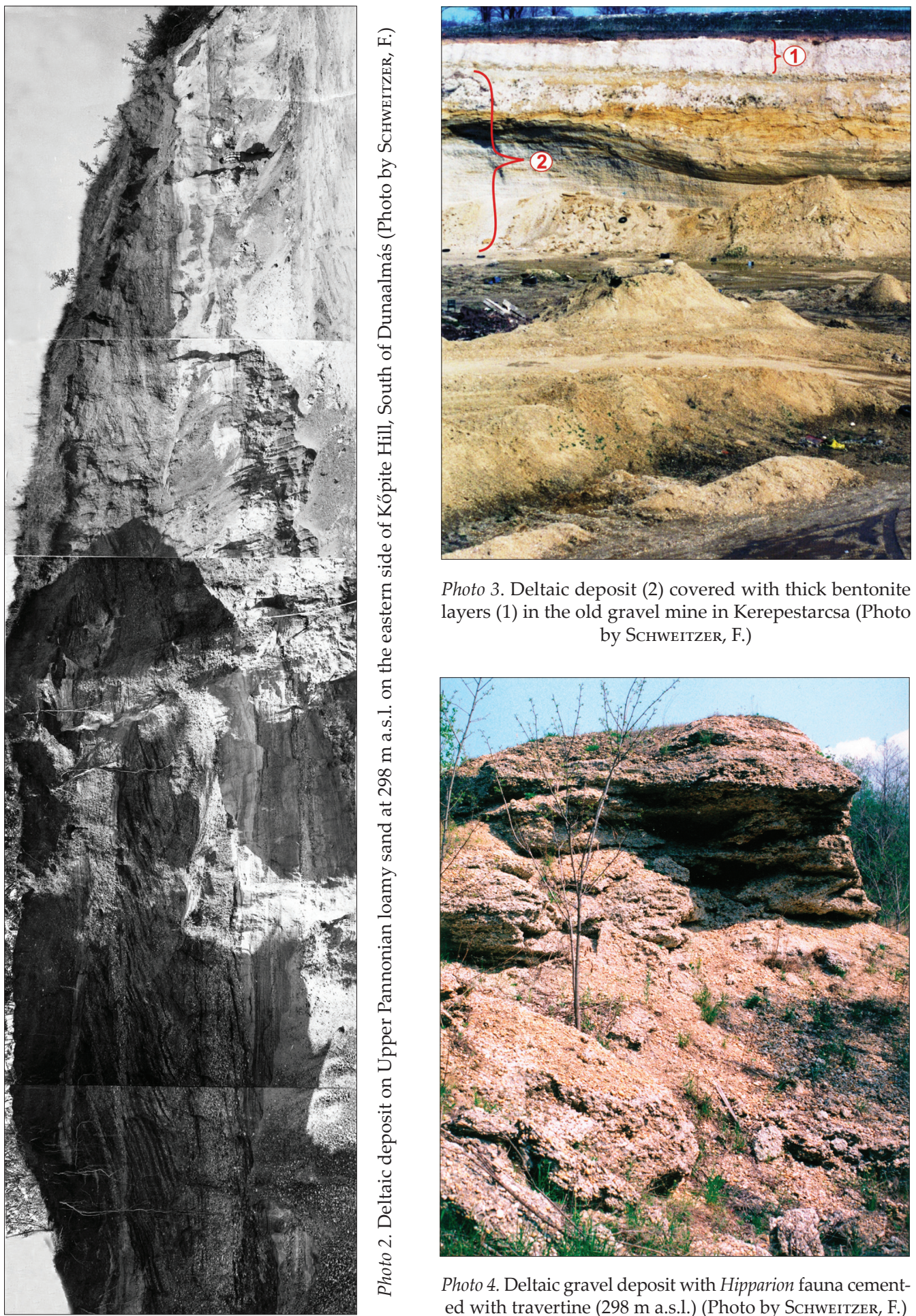

Photo 3. Deltaic deposit (2) covered with thick bentonite layers (1) in the old gravel mine in Kerepestarcsa (Photo by Schweitzer, F.)

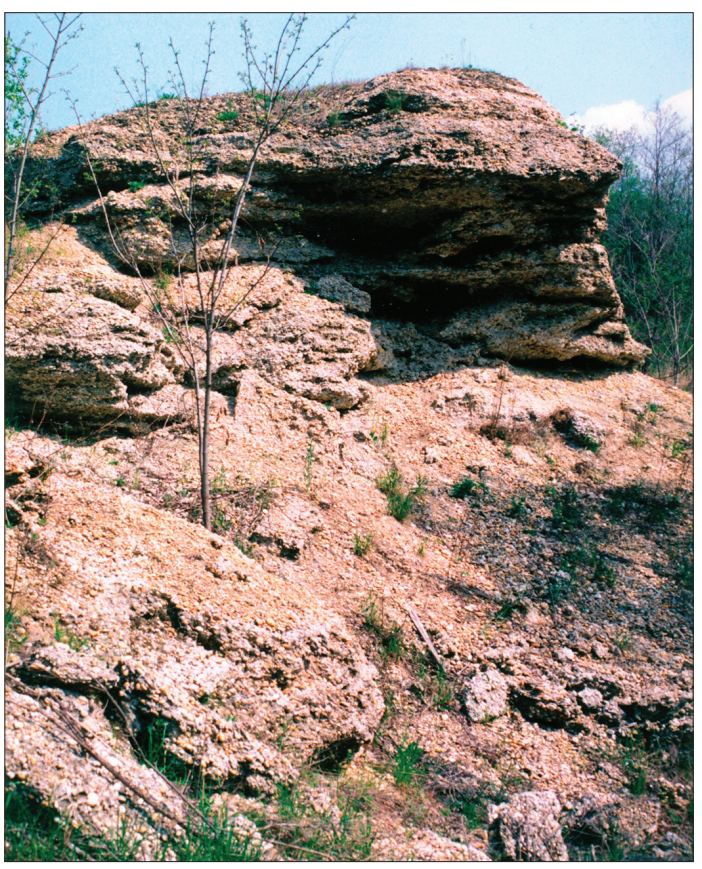

Photo 4. Deltaic gravel deposit with Hipparion fauna cemented with travertine (298 $\mathrm{m}$ a.s.l.) (Photo by Schwertzer, F.) 


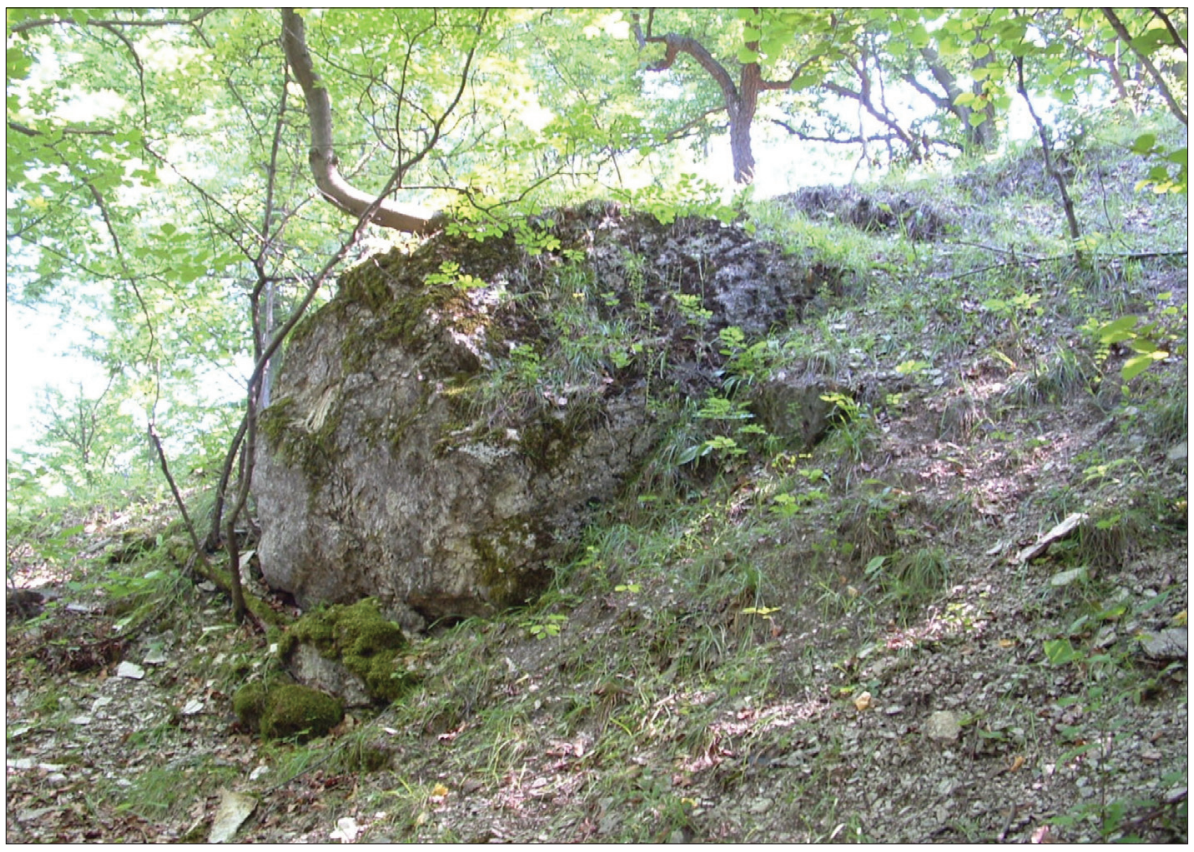

Photo 5. Remnants of geyser cones in Magyarkút at $230 \mathrm{~m}$ a.s.l. Their evolution is related to post-volcanic activities of andesitic volcanism (Photo by SzeberénYI, J.)

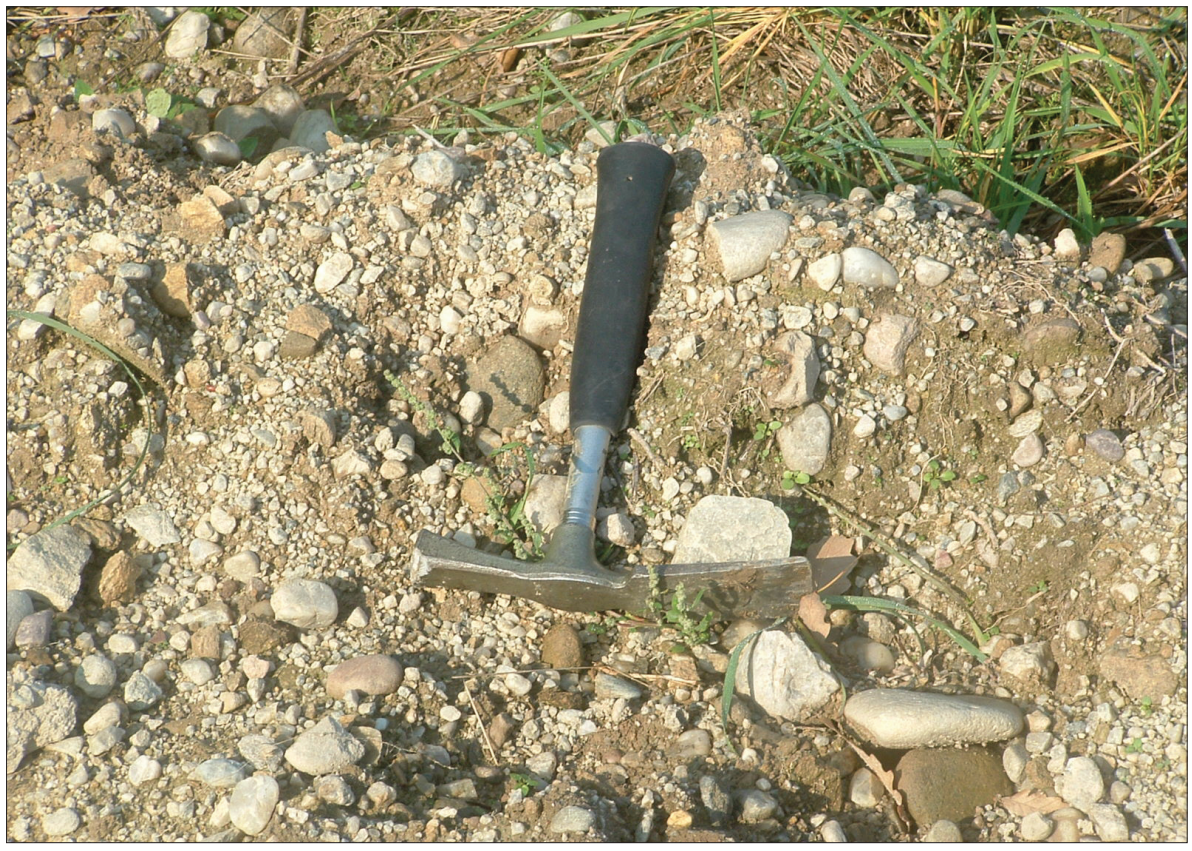

Photo 6. Gravel deposit of 2-3 m thickness made up of mainly rolled quartz pebbles in Királyrét-Nógrád (Photo by Szeberényi, J.) 


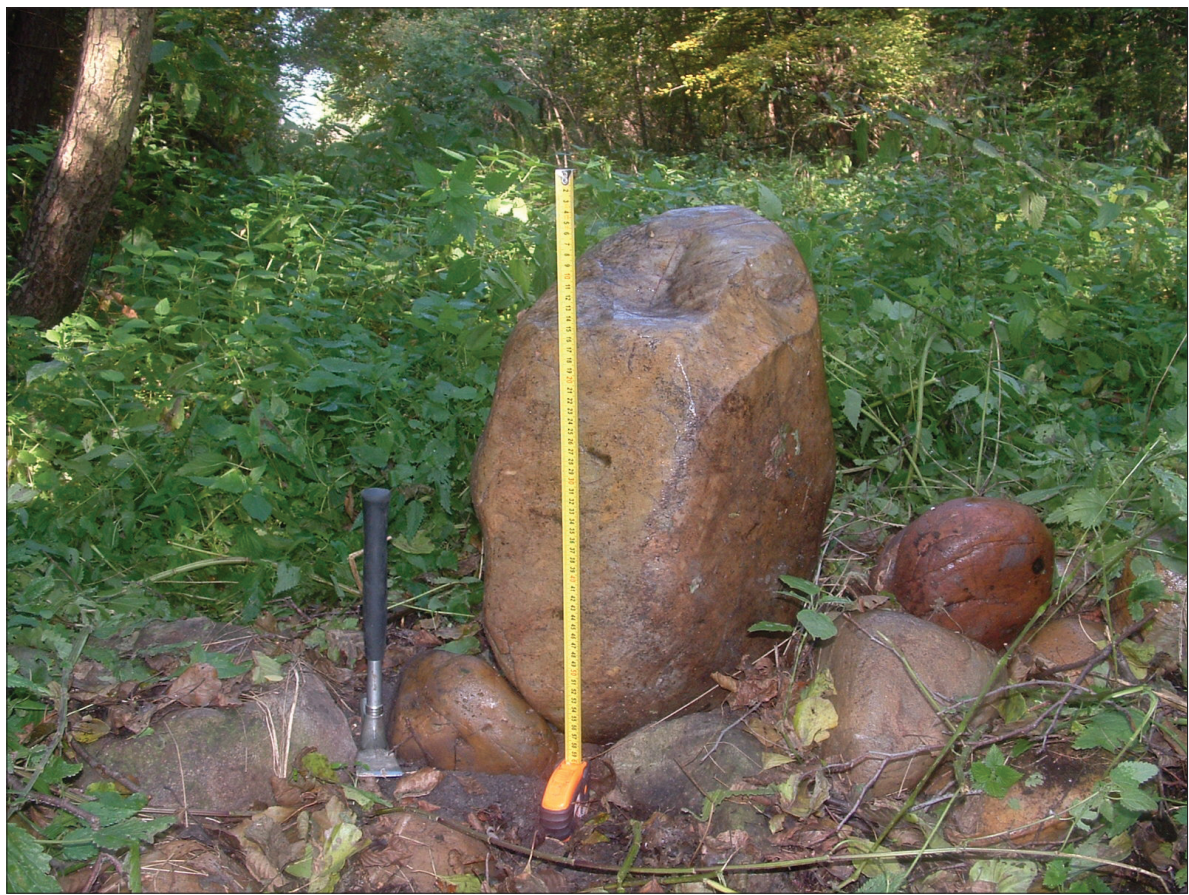

Photo 7. Large, rolled, dreikanter-like quartz boulder of 50-60 cm diameter at 290-300 m a.s.l. (Photo by SzeberénYi, J.)

ating a natural barrier hindering the southward opening of "Visegrád Gorge". Thus, thinking of the strait as a link towards Nógrád through the Szokolya Basin is only a hypothesis (Figure 9, Photo 8).

The interfluve ridge between Visegrád and Verőce was also formed by headward erosion as it was previously referred to by KÁDÁR, L. (1955) as well. Furthermore, it is remarkable that sporadically occurring pebbles and strath terraces can be observed on the geomorphological surfaces of the Danube Bend at the height of 230-330 $\mathrm{m}$ a.s.l. (the northern rim of Gerecse Hills) and at the height of 350-370 $m$ a.s.l. between Dunaalmás and NagymarosVisegrád, however, the pebble deposits are completely missing and only young terraces evolved below the height of 180-200 m a.s.l., along the section of Verőce-DunabogdányBudapest. The latter ones, nevertheless, can be detected on both sides of the Danube between Dunaalmás and Budafok and they can also be detected in the cores sampled in the Great Hungarian Plain (NoszKY, J. 1933; LÁng, S. 1953; KÉz, A. 1956; Pécsi, M. 1959; RónAI, A. 1972) (Figure 9).

There are further evidences for the existence of the ancient "Visegrád Gorge" in Zebegény at the height of 180-190 m a.s.1. where the patches of coarse sand deposited on andesite in several places are good examples for the fact that the shallow coral bays which evolved during the Badenien Stage (13-14 Ma BP) later were covered and temporarily buried either by fluvial sand or under arid, semi-arid climate by fluvial and eolic sand, namely, in the Sarmatian Stage (12-13 Ma BP) and in the upper stages of Late Miocene (7-5 Ma BP).

That's how the ancient Danube and its tributaries having filled up with sediments the the system of shallow lakes which became brackish and later fresh water lakes during the Late Miocene. 


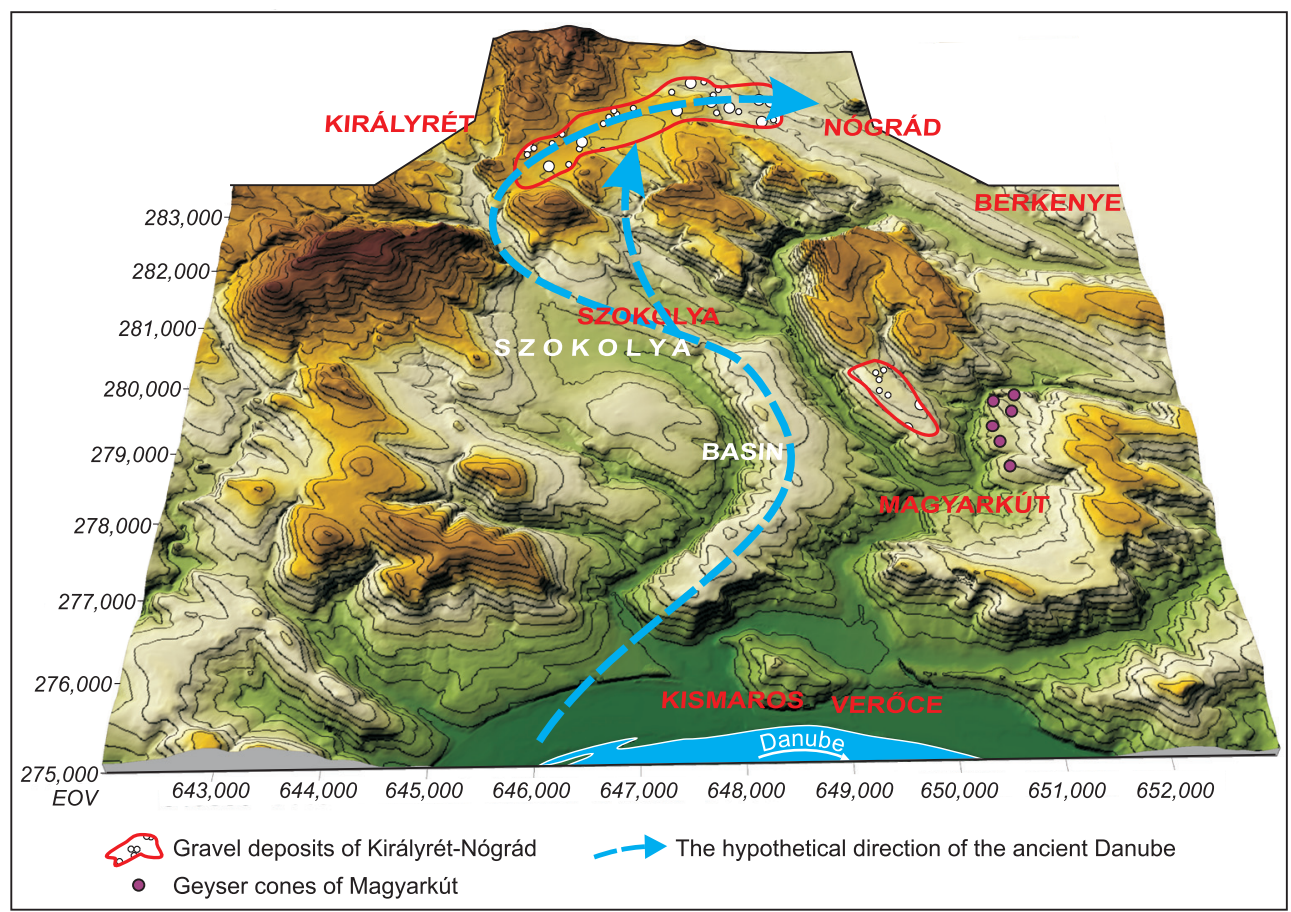

Fig. 8. Locations of gravel deposits of Királyrét-Nógrád, the geyser cones of Magyarkút in the vicinity of Szokolya Basin (based on SchweITzer's hypothesis)

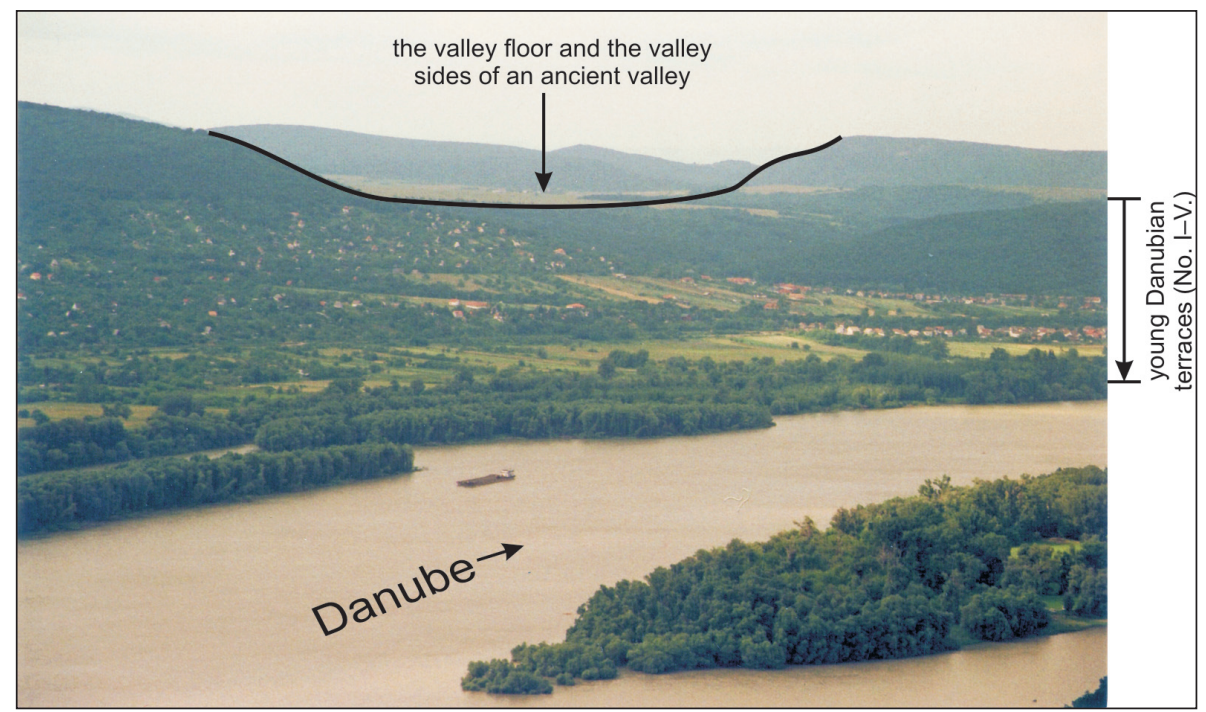

Photo 8. Ancient erosional valley between Nagymaros and Verőce (240-250 m a.s.1.) and 140-150 m relative height above the Danube. It can be followed all along the Morgó Stream in the direction of Szokolya-Királyrét. On the left and right side of the photo the younger Danube terraces can be seen at $180 \mathrm{~m}$ a.s.l. and below

(Photo by Schweitzer, F.) 


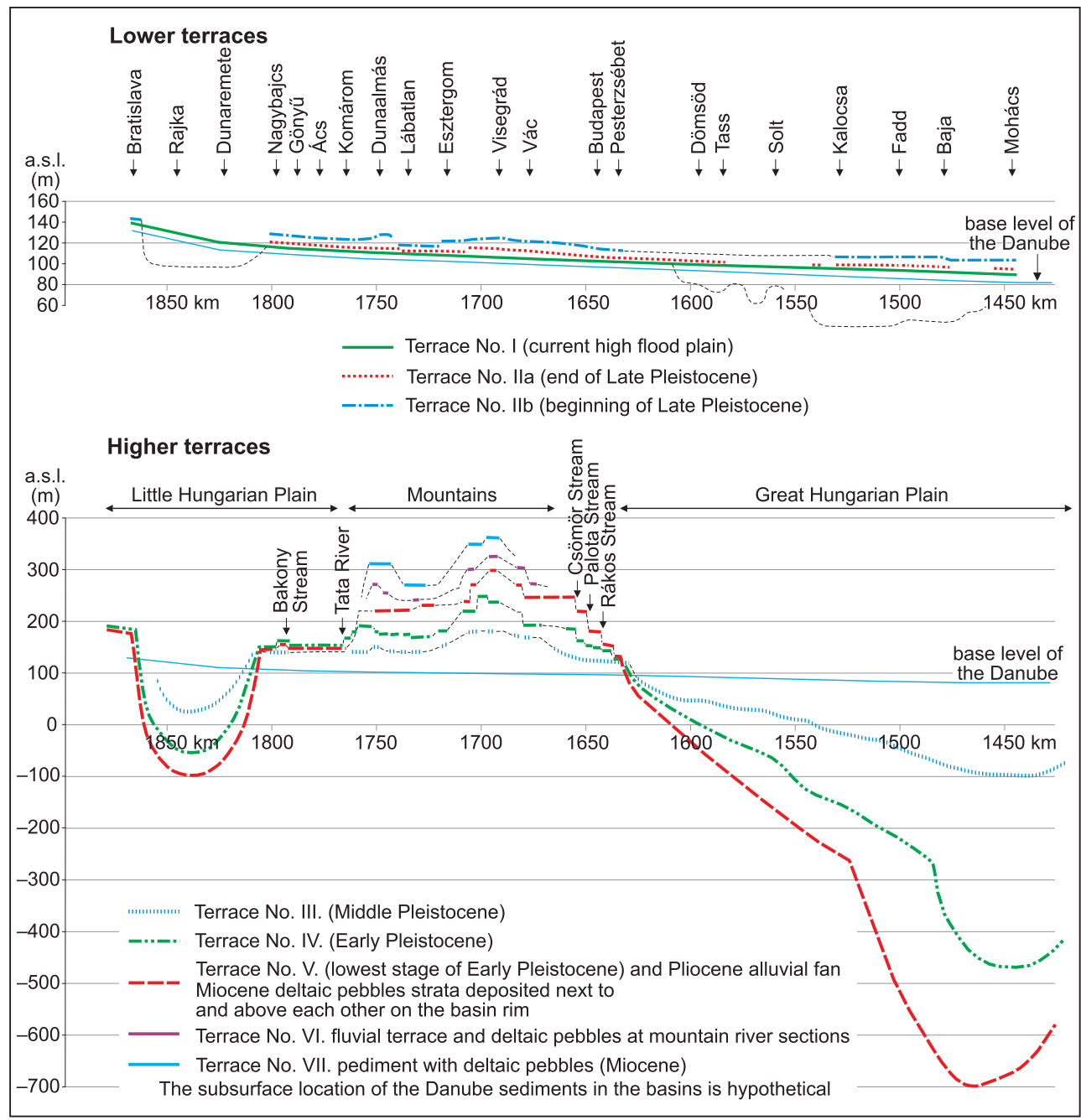

Fig. 9. The locations of Danube terraces along the Hungarian section of the Danube (based on the works of PÉcsi, M.)

\section{Drainage system development in the Carpathian Basin}

At the end of the Late Miocene Sub-Epoch (7-8 Ma BP) and at the beginning of Pliocene Epoch significant changes took place in the Carpathian Basin. As a result of a dynamic global climate change, the previous warm and humid subtropical climate turned into drier, warmer and more extreme resulting in the dramatic shrinkage, gradual accumula- tion and dry-up of Lake Pannon. The climax of that period was the so called Bérbaltavárian Stage (Kretzoi, M. 1969; Kordos, L. 1991, 1992; Kretzoi, M. and Pécsi, M. 1979) which is equivalent to the Messinian salinity crisis considering the international nomenclature of geological timescale (Schweitzer, F. 1993, 2004). The fauna findings (jirds /Meriones/, Giraffidae, Hipparion and Anthilope species) of the Carpathian Basin (Kormos, T. 1911; KRETzoI, M. 1962; Kordos, L. 1992) (Figure 10) and 


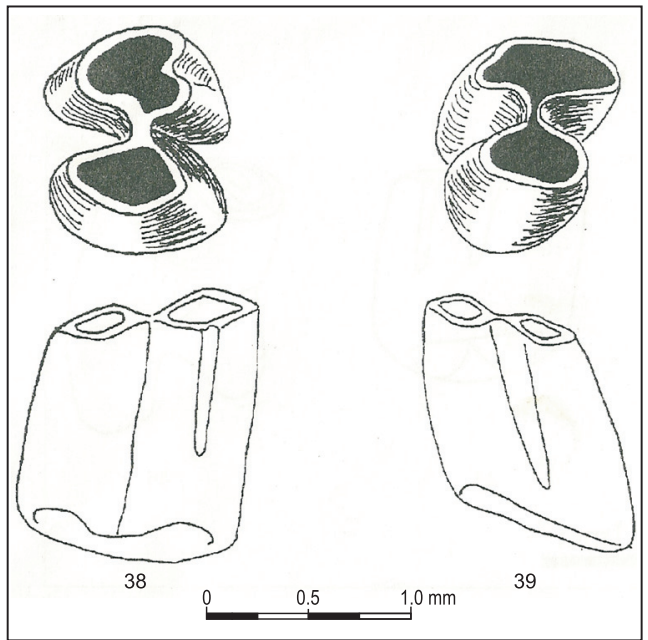

Fig. 10. Epimeriones (gerbils) molars found in crossbedded sand in Egyházasdengeleg (by Hir, J. and MÉszáros, L.Gy. 1995)

its environment provide an evidence for the hot and dry semi-arid climate evolved as a consequence of global climate change.

During the Bérbaltavárian stage a hot and dry semi-arid climate evolved in the Carpathian Basin where large sand dunes and torrents with riparian forests appeared (Mотть, M. 1941). Arid and semi-arid areas characterized by sedimentary rock formations with limestone, dolomite and gypsum were dominant in the basin (SCHWEITZER, F. 1993; Schweitzer, F. and Szöố, GY. 1997). Under the hot and dry climate the fragmentation of rocks resulted in the accumulation of huge amount of sand deposited over the mudrocks of Lake Pannon in varying thickness $(50-200 \mathrm{~m})$. The investigations pointed out that the torrents crossing the Little Hungarian Plain had been flowing southwards in the direction of Slavonic Basin, then they accumulated the whole Little Hungarian Plain (SzÁdeczKy-Kardoss, E. 1939; SüMeghy, J. 1953). The siliceous crust is an evidence for the arid climate characterized by an annual mean precipitation of only 150-250 mm conducive to the evolution of torrents but not to that of fluvial terraces (Schweitzer, F. and Szöőr, Gy. 1997).

During the Lower Pannonian Stage (Eppelsheimium in the Hungarian terminology) the tropic rainforests which previously had covered even regions at higher latitudes contracted to a smaller area around

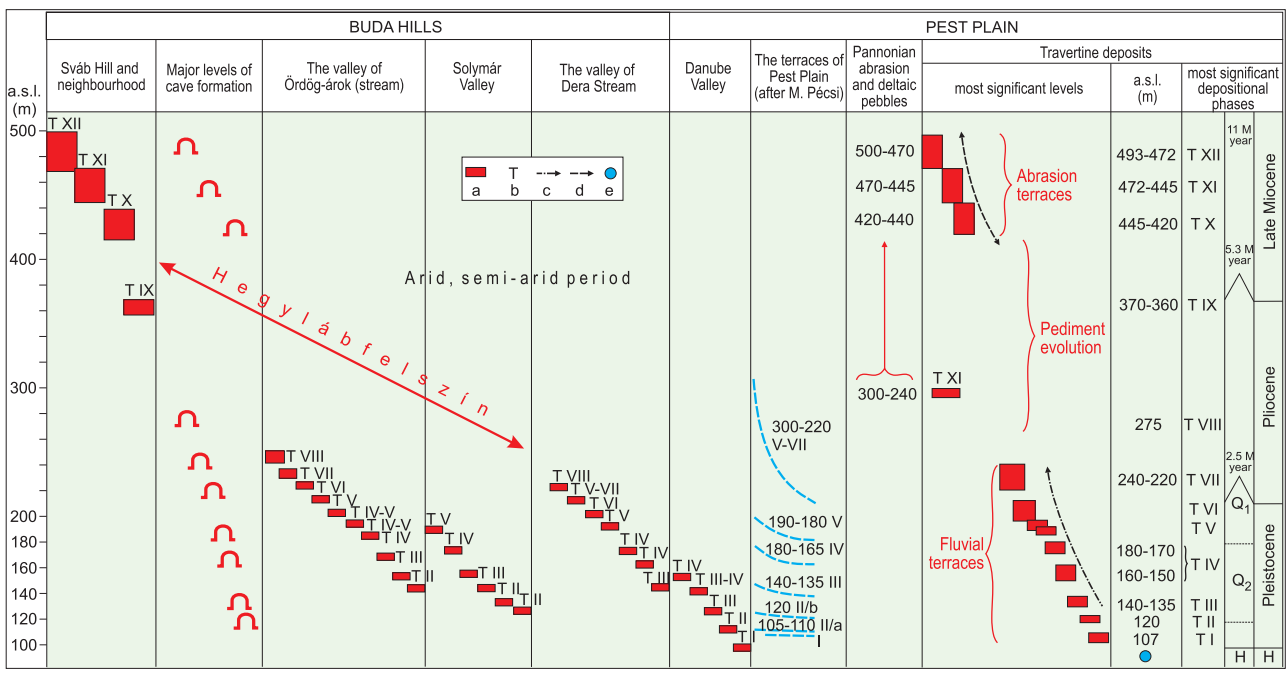

Fig. 11. The evolution and the development of drainage network in the Carpathian Basin based on travertine stratigraphy (by Schweitzer, F. 1993-2013). - a = travertine levels (by Scheuer, Gy. and Schweitzer, F. 1984); $\mathrm{b}=$ the most important levels of travertine deposition; $\mathrm{c}=$ travertine deposition on valley sides; $\mathrm{d}=$ the tectonic elevation of János Hill and Sváb Hill; e = the level of resurgence of recent karst springs 
the Equator due to the global climate change. Then under the warm and humid climate of the Late Pliocene (Csarnotanian Stage, 4-3 Ma BP) favouring red clay development, tropic rainforests expanded again. The development of the drainage system of the Danube and the whole Carpathian Basin lasting until the present time (Kretzor, M. and PÉCSI, M. 1979; Scheuer, Gy. and Schweitzer, F. 1988; SCHWEITZER, F. 1993) (Figure 11) also started and the rivers dissected the pediments which evolved during the warm and dry period of Bérbaltavárian (Messinian) Stage.

\section{REFERENCES}

Bulla, B. 1941. A Magyar medence pliocén és pleisztocén teraszai (The Pliocene and Pleistocene terraces in the Hungarian Basin). Földrajzi Közlemények 69. (4): 199-230.

Bulla, B. 1956. A magyar föld domborzata fejlődésének ritmusa az újharmadkor óta a korszerü geomorfológiai szemlélet megvilágításában (The rhythm of the terrain evolution of the Hungarian land since the Late Tertiary in the light of a modern geomorphological approach). Az MTA Társadalmi-Történeti Tudományok Osztályának Közleményei 7. (4): 281-296.

Cholnoky, J. 1915. Budapest földrajzi helyzete (Geographical position of Budapest). Földrajzi Közlemények 43. (5): 193-225.

CHоLnoky, J. 1929. Magyarország földrajza (Geography of Hungary). Pécs, Danubia. 167 p.

Cvijıć, J. 1908. Entwicklungsgeschichte des Eisernen Tores. Petermanns Geographische Mitteilungen, Ergänzungsheft 160. 1-64.

CvijIĆ, J. 1910. The evolution of Lake Eordean during the Diluvium age. Glasnik srpske Kraljevske Akademije 81. 1-84. (in Serbian)

ERDÉLYI, M. 1955. A Dunavölgy nagyalföldi szakaszának víztároló üledékei (The aquifers situated along the Danube in the Great Hungarian Plain). Hidrológiai Közlöny 35. (5-6): 159-169.

FINK, J. 1961. Der östliche Teil des nördlichen Alpenvorlandes. Mitteilungen der Österreichischen Bodenkundlichen Gesellschaft 6. 25-51.

FInK, J. 1967. Die Paläogeographie der Donau. In Limnologie der Donau: eine monographische Darstellung. Ed. Liepolt, R. Stuttgart, Schweizerbart. 1-50.

FINK, J. and MajDan, H. 1954. Zur Gliederung der pleistozanen Terrassen des Wiener Raumes. Jahrbuch der geologischen Bundesanstalt 97. (2): 211-249.

Funder, S., Abrahamsen, N., Bennike, D. and FeylingHANSEN, R.W. 1985. Foresterd Arctica: evidence from North Greenland. Geology 13. 542-546.
GÁвris, Gy. 2006. A magyarországi folyóteraszok kialakulásának és korbeosztásának magyarázata az oxigénizotóp-sztratigráfia tükrében (The explanation of the evolution and the chronology of the Hungarian fluvial terraces in the light of oxygen isotope stratigraphy). Földrajzi Közlemények 54. (3-4): 123-133.

Halaváts, Gr. 1898. A Budapest vidéki kavicsok kora (The age of the gravels located in the vicinity of Budapest). Földtani Közlöny 28. (10-11): 291-299.

HaQ, B.U., Hardenbol, J. and Vail, P.R. 1987. Chronology of fluctuating sea levels since the triassic. Science 235. 1156-1167.

Hir, J. and Mészáros, L.Gy. 1995. Late Miocene Microvertebrata from Egyházasdengeleg (North Hungary, Nógrád County). Nógrád Megyei Múzeumok Évkönyve 20. Salgótarján, 167-200.

Jámbor, Á., Balázs, E., BAlogh, K., Bérczi, I., BóNA, J., Horváth, F., Gajdos, I., Geiger, J., Hajós, M., Kordos, L., Korecz, A., Korecz-LaKy, I., Korpás-Hódi, M., Kőváry, J., Mészáros, L., Nagy, E., Németh, G., Nusszer, A., Pap, S., Pogácsás, Gy., Révész, I., Rumpler, J., Sütô-SzÁntai, M., Szalay, Á., Szentgyörgyi, K., SzÉLEs, M. and VöLGYI, L. 1987. General characteristics of Pannonian s.l. deposits in Hungary. Magyar Állami Földtani Intézet Évkönyve. 70. 155-167.

Jánossy, D. 1979. A magyarországi pleisztocén tagolása gerinces faunák alapján (The Pleistocene chronology of Hungary on the basis of vertebrate fauna). Budapest, Akadémiai Kiadó. 206 p.

KÁDÁR, L. 1955. A folyókanyarulatok elmélete és a hegységek áttörésében való szerepe (The theory of river meanders and its role in the downcutting of rivers in the mountainous regions). Dunántúli tudományos gyüjtemény 5. Pécs, MTA Dunántúli Tudományos Intézet. 32 p.

KÁDÁR, L. 1980. A mi változó bolygónk, a Föld. 1. rész. Hérodotosz földrajzi adatainak megbízhatósága és ősföldrajzi jelentőségük különös tekintettel ÉszakAfrikára és Délkelet-Európára (Our changing planet the Earth. Part. 1. Reliability of Herodotus' geographical data and their paleogeographical significance with special reference to North Africa and the South-Eastern Europe). Acta Geographica ac Geologica et Meteorologica Debrecina 14-15. 110-257.

Kéz, A. 1934. A Duna győr-budapesti szakaszának kialakulásáról (On the evolution of the Danube along the river section between Győr and Budapest). Földrajzi Közlemények 62. (10-12): 175-193.

KÉz, A. 1956. Az Ôsduna és vízterülete (The ancient Danube and its watershed). Földrajzi Közlemények 4. (4): 403-408.

Kordos, L. 1991. Polgárdi, késő-miocén ősgerinces lelőhelyek (Late Miocene ancient vertebrate fauna sites in Polgárdi). Magyarország geológiai alapszelvényei, 1-6. (1985-1991), Budapest, MÁFI.

Kondos, L. 1992. Magyarország harmad-és negyedidőszaki emlősfaunájának fejlődése és biokronológiája (The evo- 
lution and the biochronology of the Tertiary and Quaternary mammal fauna in Hungary). Akadémiai doktori értekezés. Budapest, MÁFI, 104 p.

Kormos, T. 1911. A polgárdi pliocén csontlelet (The Pliocene bone artifacts found in Polgárdi). Földtani Közlöny 41. (1-2): 48-64.

Kretzoi, M. 1962. A csarnótai fauna és faunaszint (The Csarnotanian fauna and fauna level). A Magyar Állami Földtani Intézet Évi Jelentése az 1959. évről. Budapest, MÁFI, 297-395.

Kretzoi, M. 1969. Megjegyzések a föemlősök nomenklaturájához (Notes on the nomenclature of primates). Vertebrata Hungarica 11. 195-199.

Kretzoi, M. and Pécsi, M. 1979. The Pliocene and Pleistocene development and chronology of the Pannonian Basin. Acta Geologica Academiae Scientiarum Hungaricae 22. (1-4): 3-33.

Kretzor, M. 1983. Kontinenstörténet és biosztratigráfia a felső harmadkor és a negyedidőszak folyamán a Kárpát-medencében és korrelációi (The history of continents and biostratigraphy in the Upper Tertiary and the Quaternary era in the Carpathian Basin and its correlations). Földrajzi Közlemények 107. (3-4): 230-240.

KRIVÁN, P. 1953. A pleisztocén földtörténeti ritmusai: az új szintézis (The Earth's historical rhythms of Pleistocene: the new synthesis). In Az Alföld földtani felépitésének kérdései. A Magyar Tudományos Akadémia Müszaki Tudományok Osztálya Földtani Bizottsága által 1952. szeptember 26, 27 és 28-án tartott Alföldi kongresszus előadásai. Budapest, Akadémiai Kiadó, 5-15.

KüPper, H. 1953. Uroberfläche und jüngste Tektonik im südlichen Wiener Becken. In Skizzen zum Antlitz der Erde: geologische Arbeiten, herausgegeben aus Anlaß des 70. Geburtstages von Prof. Dr. L. Kober. Eds. Küpper, H. et al. Wien, Hollinek, 376-386.

LÁNG, S. 1953. A Szentendre-Visegrádi hegység felszíne (The geomorphology of Szentendre-Visegrád Hills). Földrajzi Értesítő 2. (4): 447-469.

LÁNG, S. 1955. A Gerecse peremhegységi részeinek geomorfológiája (The geomorphology of the edges of Gerecse Hills). Földrajzi Értesítő 4. (2): 157-197.

Lóczy, L. 1913. A Balaton környékének geológiai képződményei és ezeknek vidékek szerinti telepedése. A Balaton tudományos tanulmányozásának eredményei (The geological formations of the vicinity of Lake Balaton by regions. The results of the scientific study of Lake Balaton). 1. kötet. 1. rész. 2. szakasz. Budapest, Magyar Földrajzi Társaság Balaton Bizottsága, 617 p.

MıнÁLcz, I. 1953. Az Alföld negyedkori üledékeinek tagolódása (The Quaternary sedimentary strata in the Great Hungarian Plain). In Az Alföld földtani felépitésének kérdései: Magyar Tudományos Akadémia Müszaki Tudományok Osztálya Földtani Bizottsága által 1952. évi szeptember 26,
27 és 28-án tartott Alföldi kongresszus előadásai. Budapest, Akadémiai Kiadó. 101-110.

Mотть, M. 1941. Pliocén problémák és a plio-pleisztocén határkérdés (Pliocene related problems and the question of the boundary between the Pliocene and the Pleistocene). Beszámoló a Magyar Királyi Földtani Intézet vitaüléseinek munkálatairól: a M. Kir. Földtani Intézet évi jelentésének függeléke. Budapest, Mkir FI, 43-63.

NoszKy, J. 1933. Adatok a visegrádi Dunaszoros terraszképződményeinek geológiai ismeretéhez: jelentés az 1933. évi geológiai felvételekröl (Data for the geological knowledge on the terraces of the Danube Strait in Visegrád. Report on the geological surveys for the year 1933). A Magyar Királyi Földtani Intézet Évi Jelentései az 1933-35. évekről 4. Budapest, Mkir FI, 1523-1541.

PAPP, A. 1950. Übergangsformen von Congeria zu Dreissena aus dem Pannon des Wiener Beckens. Annalen des Naturhistorischen Museums in Wien 57. 148-156.

PÉcsi, M. 1959. A magyarországi Duna-völgy kialakulása és felszinalaktana (The evolution and the geomorphology of the Danube Valley in Hungary). Földrajzi monográfiák 3. Budapest, Akadémiai Kiadó, 345 p.

Pécsi, M. 1980. A Pannóniai-medence morfogenetikája (The morphogenesis of the Pannonian Basin). Földrajzi Értesítö 29. (1): 105-127.

PÉcsi, M. 1985. The Neogene red clays of the Carpathian Basin. In Problems of the Neogene and Quaternary in the Carpathian Basin: geological and geomorphological studies. Eds.: Kretzor, M. and M. PÉcsI, M., Studies in Geography in Hungary 19. Budapest, Akadémiai Kiadó, 89-98.

Pécsi, M., Scheuer, Gy., Schweitzer, F., Hahn, Gy. and Pevzner, M.A. 1985. Neogene - Quaternary geomorphological surfaces in the Hungarian mountains. In Problems of the Neogene and Quaternary in the Carpathian Basin: geological and geomorphological studies. Eds.: Kretzoi, M. and M. Pécsi, M., Studies in Geography in Hungary 19. Budapest, Akadémiai Kiadó, 51-63.

PENCK, A. 1894. Morphologie der Erdoberfläche. Teil 2. Stuttgart, Engelhorn, 696 p.

Penck, A. 1910. Der XI. International GeologenKongress fand am 17-25. August d. J. in Stockholm statt. Zeitschrift der Gesellschaft für Erdkunde zu Berlin. 471-474.

Prinz, Gy. 1936. Magyar föld, magyar faj (Hungarian land, Hungarian species). 1. kötet, Magyar földrajz. 1. rész, Magyarország tájrajza. Budapest, Királyi Magyar Egyetemi Nyomda, 394 p.

RóNAI, A. 1972. Negyedkori üledékképződés és éghajlattörténet az Alföld medencéjében (Quaternary sedimentation and paleoclimatology in the Great Hungarian Plain). A Magyar Állami Földtani Intézet évkönyve 56.1. Budapest, MÁFI, 1-421. 
Salamon, F. 1878. Buda-Pest története. Első rész: BudaPest az ó-korban. (The history of Buda-Pest. BudaPest during the Antiquity). Budapest, 366 p.

Scheuer, Gy. and Schweitzer, F. 1984. Budai és Gerecse hegységi édesvízi mészkövek kőzetrepedezettségi jelenségei (Fractures in travertine in the Buda and Gerecse Hills). Épitóanyag 36. 121-129.

Scheuer, Gy. and Schweitzer, F. 1988. A Gerecse-és a Budaihegység édesvízi mészkőösszletei (Travertine deposits in the Gerecse and Buda Hills). Földrajzi Tanulmányok 20. Budapest, Akadémiai Kiadó, 129 p.

Schlesinger, G. 1912. Studien über die Stammesgschichte der Proboscidier. Jahrbuch der geologischen Reichsanstalt 62. (1): 1-182.

Schweitzer, F. 1993. Domborzatformálódás a Pannóniaimedence belsejében a fiatal újkorban és a negyedidószak határán (Terrain Evolution in the Pannonian Basin during the Late Cenozoic Era and around the Quaternary boundary). Budapest, MTA Földrajztudományi Kutatóintézet, 125 p. Manuscript.

Schweitzer, F. 2004. On the possibility of cyclic recurrence of ice ages during the Neogene. Földrajzi Értesító 53. (1-2): 5-11.

SchweItzer, F. and Szöőr, Gr. 1997. Geomorphological and stratigraphical significance of Pliocene red clay in Hungary. Zeitschrift für Geomorphologie. Supplementband. 110. 95-105.
SóвÁNYI, Gy. 1893. A törmelék-kúpok keletkezése (The evolution of debris cones). Földrajzi Közlemények 21. (1): 11-25.

SteInINGER, F.F. 1999. Chronostratigraphy, Geochronology and Biochronology of the Miocene "European Land Mammal Mega-Zones" (ELMMZ) andhe Miocene „Mammal-Zones (MN-Zones). In The Miocene Land Mammals of Europe. Eds.: Rössner, G.E. and HeIsig, K. München, Verlag dr. Friedrich Pfeil, 9-24.

Ströмpl, G. 1913. A visegrádi Duna-szoros és a pesti síkság kavicstelepei (The gravel deposits of the Duna Strait in Visegrád and in Pest Plain). Földtani Közlöny 43. (7-9): 328-331.

Sümeghy, J. 1953. Medencéink pliocén és pleisztocén rétegtani kérdései (Questions on the Pliocene and Pleistocene stratification of our basins). A Magyar Állami Földtani Intézet Évi Jelentése az 1951. évről. Budapest, MÁFI, 83-109.

SzÁdeczKy-Kardoss, E. 1939. A Gerecse hegység magasterraszairól (On the high terraces of the Gerecse Hills). Földtani Közlöny 69. (10-12): 279-288.

Thenius, E. 1978. Neue Säugetierfunde aus dem Pliozän von Niederösterreich [Rhinoceros megarhinus]. Mitteilungen der Österreichischen Geologischen Gesellschaft 68. 109-128.

Zubakov, V.A. and Borzenkova, I.I. 1990. Global paleoclimate of the late Cenozoic. Amsterdam, Elsevier, 456 p. 


\title{
Changing Ethnic Patterns of the Carpatho-Pannonian Area from the Late $15^{\text {th }}$ until the Early $21^{\text {st }}$ Century
}

\author{
Edited by: Károly KOCSIS and Patrik TÁTRAI \\ Hungarian Academy of Sciences, Research Centre for Astronomy and Earth Sciences \\ Budapest, 2013.
}

This is a collection of maps that visually introduces the changing ethnic patterns of the ethnically, religiously, culturally unique and diverse Carpathian Basin and its neighbourhood, the Carpatho-Pannonian area.

The Hungarian and English volume consist of three structural units. On the main map, pie charts depict the ethnic structure of the settlements in proportion to the population based on census data et the millennium. In the supplementary maps, changes of the ethnic structure can be seen at nine dates (in 1495, 1784, 1880, 1910, 1930, 1941, 1960, 1990 and 2001). The third unit of the work is the accompanying text, which outlines the ethnic trends of the past five hundred years in the studied area.

The antecedent of this publication is the "series of ethnic maps" published by the Geographical Research Institute of the Hungarian Academy of Sciences from the middle of the 1990's, which displayed each of the regions of the Carpathian Basin (in order of publication: Transylvania, Slovakia, Transcarpathia, Pannonian Croatia, Vojvodina, Transmura Region, Burgenland,

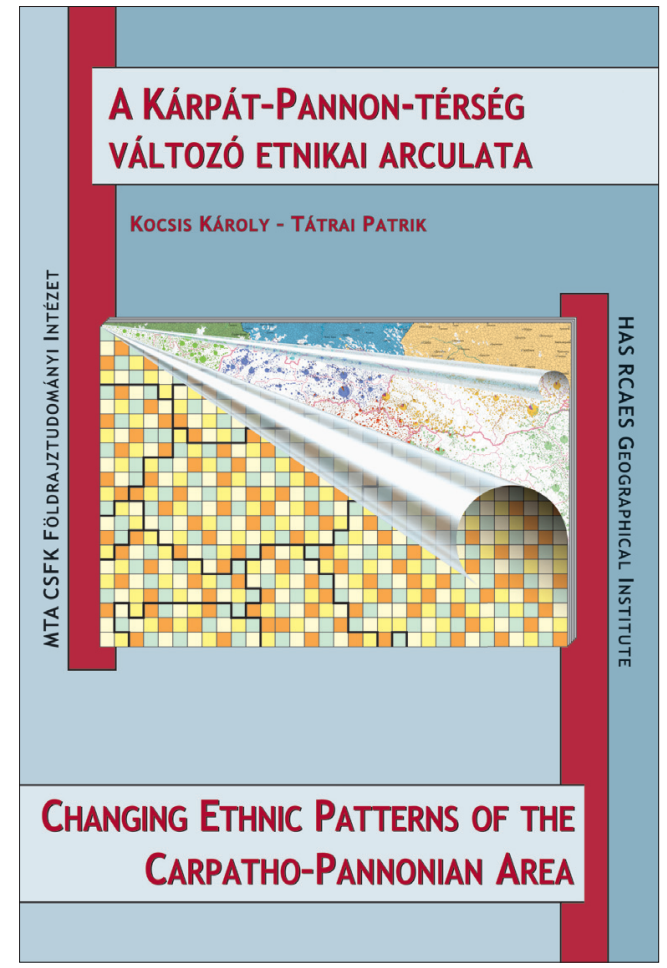
Hungary). This work represents, on the one hand, the updated and revised version of these areas, and, on the other hand, regions beyond the Carpathian Basin not included on previous maps. Thus, the reader can browse ethnic data of some thirty thousand settlements in different maps.

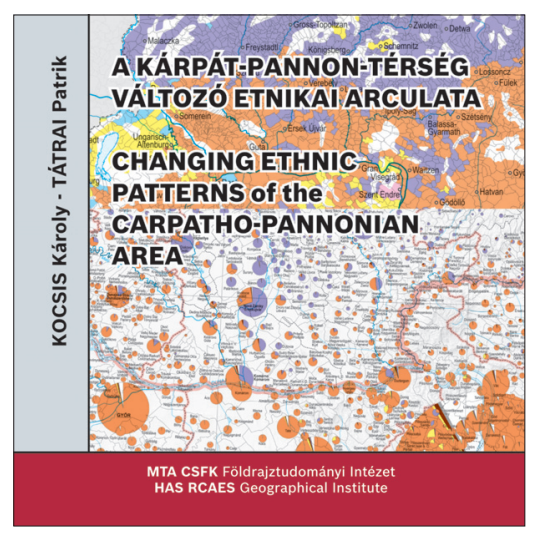

Price: EUR 12.00

Order: Geographical Institute RCAES HAS Library H-1112 Budapest, Budaörsi út 45.

E-mail: magyar.arpad@csfk.mta.hu 